\title{
Environmental/lifestyle factors in the pathogenesis and prevention of type 2 diabetes
}

\author{
Hubert Kolb ${ }^{1,2^{*}}$ and Stephan Martin ${ }^{1,2}$
}

\begin{abstract}
Background: Environmental and lifestyle changes, in addition to the ageing of populations, are generally believed to account for the rapid global increase in type 2 diabetes prevalence and incidence in recent decades.

Discussion: In this review, we present a comprehensive overview of factors contributing to diabetes risk, including aspects of diet quality and quantity, little physical activity, increased monitor viewing time or sitting in general, exposure to noise or fine dust, short or disturbed sleep, smoking, stress and depression, and a low socioeconomic status. In general, these factors promote an increase in body mass index. Since loss of $\beta$-cell function is the ultimate cause of developing overt type 2 diabetes, environmental and lifestyle changes must have resulted in a higher risk of $\beta$-cell damage in those at genetic risk. Multiple mechanistic pathways may come into play.

Conclusions: Strategies of diabetes prevention should aim at promoting a 'diabetes-protective lifestyle' whilst simultaneously enhancing the resistance of the human organism to pro-diabetic environmental and lifestyle factors. More research on diabetes-protective mechanisms seems warranted.
\end{abstract}

Keywords: Type 2 diabetes, Environment, Lifestyle, Diabetes risk factors, Diabetes prevention, Diet, Physical activity, $\beta$-cells

\section{Background}

Over the past decades, there has been a major increase in type 2 diabetes (T2D) prevalence in most regions of the world [1]. After adjusting for the impact of ageing populations, diabetes prevalence in adults $(85-95 \%$ T2D) almost doubled between 1980 and 2014 worldwide. Increases were more pronounced in low- and middle-income countries and in men compared to women [1].

Recognition of the environmental and lifestyle factors responsible for these changes in theory may lead to the development of strategies to decrease the number of new cases to reach those of 20-40 years earlier. This review presents the current state of knowledge and discusses the possible mechanisms involved and the consequences for strategies of diabetes prevention.

\footnotetext{
* Correspondence: hubert.kolb@uni-duesseldorf.de

${ }^{1}$ Faculty of Medicine, University of Duesseldorf, Duesseldorf, Germany

${ }^{2}$ West-German Centre of Diabetes and Health, Duesseldorf Catholic Hospital Group, Hohensandweg 37, 40591 Duesseldorf, Germany
}

\section{Overview of environmental and lifestyle factors increasing T2D risk}

It is generally believed that an energy-dense Western style diet in conjunction with a sedentary lifestyle are the primary cause of T2D [2]. These two factors are also held responsible for the current global epidemic of obesity, which is closely associated with the rising rate of T2D [3]. At closer analysis, a high body mass index (BMI) appears to contribute less to an increased risk of T2D than the presence of increased visceral obesity [4] and/or ectopic fat (liver fat) [5-7]. This fits with the observation that obese people without metabolic dysregulation have little visceral obesity or liver fat [8-10]. Conversely, people who develop T2D despite being merely overweight or within a normal weight range, such as in Asia, exhibit visceral obesity and ectopic fat deposition and reduced muscle mass, together resulting in a normal or near normal BMI [11-13]. Interestingly, a substantial age-corrected rise of T2D cases in recent decades was also seen in countries with no major change in the availability of food such as in Western Europe [1]. This suggests that additional environmental and lifestyle factors contributed to the increased 
risk of T2D. A list of factors associated with risk of T2D is shown in Box 1.

\section{Diet}

When considering the wide range of diet types consumed in different regions of the world, it may not be surprising that prospective epidemiological studies vary somewhat in the association of food groups with incident T2D. In general, plant food is associated with lower T2D risk than meat, low energy density food is considered more protective than high density energy food, associations of fish consumption with diabetes risk are variable, and fermented dairy products may be more beneficial than non-fermented ones. Further, refined grains or sugar-sweetened beverages consistently appear to promote obesity and diabetes risk [14-24]. Daily consumption of a handful of nuts may afford some protection from T2D, despite nuts representing a high energy density food [25]. Unfortunately, epidemiological studies cannot exclude the impact of confounding

\section{Box 1. Lifestyle characteristics conferring risk $^{\mathrm{a}}$ for type 2 diabetes as suggested by epidemiological studies}

Diets poor in fibre, phytochemicals or plant food in general

(relative risk increase by $44 \%$ to three-fold $[14,15]$ )

Regular consumption of sugar-sweetened beverages (relative risk

increase by 20-30\% compared to non-consumption [22-24])

Little physical activity (leisure time/occupational) (relative risk

approximately $40 \%$ higher compared to high total physical activity

$[41,42])$

Prolonged TV and monitor viewing/sedentary time (relative risk

increased by approximately 3\% per hour television watching [49])

Exposure to road traffic (noise, fine particulate matter) (relative

risk increased by 20-40\% for exposure to $10 \mathrm{~dB}$ higher noise

level or $10 \mu \mathrm{g} / \mathrm{m}^{3}$ more of fine dust particles [55-59])

Smoking (relative risk increased by approximately 30\%/60\% for

light/heavy smokers [85])

Short sleep duration and poor quality (relative risk increased by

approximately 9\% for every hour of shorter sleep duration [63])

Low mood/stress/depression (relative risk increase highly

variable, depending on definition of stress and depression)

Low socioeconomic position (relative risk increased by $40-100 \%$

when compared to high socioeconomic level [99-101])

Infection with hepatitis C virus or Chlamydia pneumoniae (no

epidemiological data on relative risk increase available)

${ }^{a}$ All factors remain significantly associated after statistical

adjustment for body mass index (BMI) and other confounders,

as described in the text. Virtually all non-infectious pro-diabetic

lifestyle characteristics promote an increase in $\mathrm{BMI}$ and waist

circumference. factors such as those of physical activity, which is difficult to assess in queries or interviews.

The most recent recommendation by the Government of the USA no longer focusses on setting limits for the amount of carbohydrates, fat and protein in foods but rather proposes food types or patterns such as a healthy US-style eating pattern, a Mediterranean diet or a vegetarian diet [26].

In order to test for cause-effect relationships, the effect of a given diet on metabolic control has been studied extensively in controlled trials with the assumption that short-term effects may indicate long-term outcomes. In the results published, most of the diets assessed were reported to improve metabolic control and lipid status, regardless of whether they were high or low in carbohydrates, fats or protein [27-31]. In many of these studies, given the unavoidable study effect (Hawthorne effect) on eating behaviour, participants consumed less calories than before the trial, at least during the first weeks, and therefore lost weight. In other trials, a hypocaloric diet was given to all study groups [31]. As a consequence, weight reduction (and concomitantly less visceral obesity) probably led to improved metabolic control, largely independent of the diet tried. Hence, the outcome of many dietary trials may give rise to misleading conclusions on the suitability of a diet for diabetes prevention in the long term.

Unfortunately, long-term trials of selected food groups for diabetes prevention in persons at risk are difficult to perform due to poor compliance. In one successful attempt, a Mediterranean diet supplemented with either $1 \mathrm{~L}$ of virgin olive oil per week or $30 \mathrm{~g}$ nuts per day was compared, in a randomised trial, with a conventional low fat diet [32]. After 4 years, both Mediterranean diet groups exhibited a rate of progression to T2D of approximately $50 \%$ of the control low fat diet group (PREDIMED trial, group size approximately 140 persons, mean age 67 years, high cardiovascular disease risk). In this trial, calorie restriction was not intended and, on average, there was less than $1 \mathrm{~kg}$ of body weight loss per person, despite the major reduction of diabetes risk over 4 years. This suggests that there are components in the Mediterranean diet or the overall pattern that may decrease diabetes risk without the need of weight reduction. Confirmation of these data in a larger trial including also younger persons without high cardiovascular disease risk would offer a robust basis for a diabetes prevention guideline. There have been many trials of lifestyle improvement for the prevention of T2D in persons at increased risk, but these do not offer advice on a 'diabetes-protective' diet because dietary guidelines have always been combined with a strategy to reduce body weight $[33,34]$.

Can we learn from the diet of centenarians? Data for Okinawa, Sicily, Sardinia, Linda Loma (California, USA) and Bama county (China) suggest some similarity to the 
above conclusions from epidemiological studies of a 'healthy' diet, i.e. a dominance of vegetables and fruit over animal food, and of whole grains over refined carbohydrates [35-38]. However, it should not be overlooked that there is a substantial contribution from other factors to healthy ageing, such as genetic background, epigenetic DNA methylation status, physical activity or daily work until high age, an active social network, and low smoking rates and alcohol consumption $[39,40]$.

\section{Occupational and leisure time physical activity}

Epidemiological studies suggest that high versus low total physical activity is associated with a reduction in relative diabetes risk by approximately $30 \%$. All types of leisure time physical activities as well as occupational physical activity were found to be inversely associated with diabetes risk [41, 42]. The beneficial effect of exercise on insulin sensitivity and glycaemic control (by continuous glucose measurement) has also been demonstrated in controlled trials in non-diabetic individuals $[43,44]$. Reallocation of $30 \mathrm{~min}$ of sedentary time into moderate to vigorous physical activity was associated with a 15\% difference in HOMA-defined insulin sensitivity [45]. The beneficial effects of muscle work do not simply reflect the burning of calories, since enhanced physical activity leads to minimal weight loss [46].

\section{Watching TV or sedentary time}

There is a strong association between sedentary time (selfreported or objectively measured) with obesity or incident diabetes, independent of the extent of physical activity [47-51]. Increased duration of sedentary behaviour may double diabetes risk [47]. In one study, each hour of television watching increased the risk of developing diabetes over 3.2 years by $3.4 \%$ [49]. Not surprisingly, the interaction appears to be bidirectional - a sedentary lifestyle promotes obesity and vice versa [52].

Recommendations of limiting sedentary time in favour of being in upright posture and moving are based on short-term trials (reviewed in [53]) that report beneficial metabolic effects from moving (without purposeful physical exercise) compared to sitting, including less body fat gain. While sitting at a desk, energy expenditure is just $5 \%$ above the basal level, whereas the value at least doubles within minutes of standing and walking [54].

\section{Housing environment and sleep duration or quality} Epidemiological studies concur in an association between increased exposure to residential traffic, noise, and fine airborne particulate matter and a higher risk of T2D diagnosis during the following 5-12 years. The risk was higher by roughly $20-40 \%$ for persons exposed to an, at least, $10 \mathrm{~dB}$ higher noise level or to $10 \mu \mathrm{g} / \mathrm{m}^{3}$ more of fine particulate matter over 10 years, or living on a busy road. It cannot be excluded that this association is not causal, but extensive adjustments have been made for age, sex and lifestyle (including BMI and physical activity), as well as for socioeconomic status, without loss of the observed associations [55-59].

Contributing factors are the duration and quality of sleep [60]. Night-time exposure to noise or light may cause sleep disturbances [61]. Similar effects have been reported for shift-workers or for persons with decreased sleep duration due to extended working hours or leisure time activities [62]. A recent meta-analysis of prospective studies reported the lowest risk of diabetes for 7-8 hours per day of sleep and an increased risk by $9 \%$ for each 1-h shorter sleep duration [63]. Longer sleep duration or day time napping may also be a risk factor for later diabetes or metabolic syndrome, but findings are not consistent [63-66]. In controlled trials performed in sleep laboratories, sleep restriction for 5 days caused a $29 \%$ decrease of whole body insulin sensitivity [67], and a decreased glucose disposal rate was observed already after one night of 4 hours of sleep [68].

It is conceivable that other aspects of the housing environment may also modulate diabetes risk, such as the climate, UV or ionising radiation, or exposure to toxins or allergens, but this area is not well researched.

\section{Coffee, tea, alcohol and smoking}

A recent meta-analysis of coffee consumption confirmed an inverse dose-response relationship between caffeinated or decaffeinated coffee intake and risk of T2D, with a 25$30 \%$ lower risk for drinking three or more cups per day [69]. It still is not clear whether this reflects a causal relationship since controlled short-term trials only reported small changes in insulin and glucose responses to a glucose load after coffee consumption, varying from some improvement to modest impairment [70-73]. However, other inflammatory risk markers of T2D may be modified $[74,75]$. In controlled trials, tea, in particular flavanol-rich green tea, has been reported to exert a modest improvement in glycaemic control if more than three cups or the equivalent amount of green tea catechins were consumed. A meta-analysis of 22 trials reported a mean decrease of fasting blood glucose by $1.4 \mathrm{mg} / \mathrm{dL}$ [76]. Epidemiological studies suggest a modest decrease of T2D risk by $10-15 \%$ in those drinking more than three cups per day $[77,78]$.

The health risks of alcohol intake seem to be dose dependent. There is now consistent epidemiological data that moderate alcohol consumption (1-2 drinks per day) may reduce the risk of developing $\mathrm{T} 2 \mathrm{D}$ by a mean maximum of approximately $20 \%$, but possibly only in women and not in Asian populations [79, 80]. A well-controlled study of the consumption of $150 \mathrm{~mL}$ of wine for dinner in patients with T2D observed a modest improvement of cardiometabolic parameters after 2 years [81]. 
Conversely, exposure to cigarette smoke both passively and actively has been found to be associated with increased risk of T2D when compared to non-smokers [82]. Metaanalyses of prospective cohort studies reported a considerably higher relative risk of diabetes for heavy smokers (risk 1.6) than for lighter smokers (risk $~ 1.3$ ) or for former smokers (risk 1.2) [83, 84]. Interestingly, a recent study reported no association between smoking and incident T2D in a large multi-ethnic cohort, which suggests a more complex role of smoking in causing diabetes [85].

\section{Depression and stress as risk factors}

Stress at work, in social relationships or in other aspects of life is difficult to define given that it is the impact on the individual and the coping mechanisms that are probably relevant, i.e. perceived stress. Thus, the results of crosssectional or prospective studies on the association of stress with T2D have been variable [86-90]. However, a 35-year study of perceived stress in Swedish men reported a significant association with later diabetes, and a similar result was observed in persons with burn-out syndrome [91, 92]. More consistent is the observation of an increased diabetes risk in persons with symptoms of depression or anxiety, and there appears to be a bidirectional relationship between depressive mood and diabetes [89, 93-97]. Interestingly, living alone is associated with an increased risk of T2D in men (hazard ratio 1.89), but not in women [98].

\section{Impact of socioeconomic status}

An inverse association of T2D and socioeconomic position has been reported worldwide, also after separate analysis of high-, middle- and low-income countries, independent of whether measured by educational level, occupation or income [99, 100]. Low levels of socioeconomic determinants were associated with a $40-60 \%$ higher relative risk compared to the subgroup with high levels. In the English Longitudinal Study of Ageing, the lowest life course socioeconomic status group experienced a more than doubled risk of diabetes [101]. An analysis in Europe found most of the difference to be mediated by BMI [102]. A study of health behaviours in Australia found smoking and lack of physical activity as a major mediator of the increased diabetes incidence in persons with low socioeconomic status [103]. A tentative conclusion is that an increased income may lower the risk of T2D if accompanied by an appropriate change in diet and lifestyle.

\section{Infections as a cause of T2D?}

Is there any indication for an infectious origin of T2D? A non-diabetic partner of a diabetic spouse has a $26 \%$ increased diabetes risk [104], likely due to a 'contagious' lifestyle. Additionally, adenovirus subtype 36 infections have been closely associated with obesity in several regions of the world, and a causal relationship was established in animal experiments [105, 106]. However, adenovirus-36 antibodies are uncommon in T2D and are associated with increased rather than decreased insulin sensitivity [107]. Nevertheless, T2D has been clearly associated to certain infections, such as hepatitis $\mathrm{C}$ virus, which may lead to hepatic steatosis, insulin resistance, T2D and cardiovascular disease [108, 109], or Chlamydia pneumoniae, which may cause $\beta$-cell dysfunction in the context of systemic inflammation [110]. The diabetes promoting effects of antiretroviral therapy should also be mentioned here [111].

These findings argue against the presence of a specific infectious agent in the aetiology of T2D but leave room for a role of chronic infections and associated systemic inflammation in promoting insulin resistance.

\section{How may unfavourable lifestyle and environmental changes cause the current T2D epidemic?}

Under favourable lifestyle and environmental conditions, people who exhibit a high genetic or epigenetic risk are at increased risk of T2D. Diabetes risk genes seem to directly or indirectly (via insulin resistance) affect $\beta$-cell function [112]. Pima Indians are people with a strong genetic predisposition for $\mathrm{T} 2 \mathrm{D}$ and they progress to T2D even when living a 'normal' lifestyle in a 'normal' environment [113]. With an unfavourable change in lifestyle and environment between 1995 and 2010, nonPima neighbours also began to exhibit an increased diabetes rate [113].

It seems unlikely that the same type of changes in lifestyle and environment can be held responsible in countries with widely different socioeconomic, cultural, environmental and lifestyle conditions. However, it appears evident that the diverse changes in lifestyle and environment have led to an increased prevalence of the primary diabetes risk factor (aside from age), namely a rise in the mean BMI in populations worldwide [3]. Even if overall obesity seems to be levelling off, such as in a region of China [114], increases in abdominal obesity are still rising.

In a 13-year observational study in the USA [115], an initial modestly elevated BMI of 27 , when compared to an initial BMI of 22, resulted in an approximately three-fold increase of diabetes risk. Therefore, the global obesity epidemic probably translates some of the changes in lifestyle and environment into a higher T2D risk. However, in the UK, a prospective study from 1984 to 2007 found that BMI could explain only $26 \%$ of the T2D increase [116], leaving room for lifestyle factors with little impact on body weight such as lack of physical activity.

Epidemiological analyses suggest that many of the diabetes risk factors described above contribute at least in part or independently to disease development, such as amount and type of food, sedentary time, physical activity, watching TV, noise, fine dust, sleep duration, shift working, 
emotional stress, socioeconomic status and some infections (for references see above). The various risk factors are not expected to directly interact with the same target in the human organism. However, since the loss of insulin production is the ultimate cause of developing overt T2D, environmental and lifestyle factors must directly or indirectly cause $\beta$-cell damage. Concomitant morphological changes in pancreatic islets, either because of $\beta$-cell death or because of dedifferentiation, have indeed been observed in the pathogenesis of T2D [117].

Only few environmental or lifestyle factors are expected to directly affect $\beta$-cell function, possible exceptions are high levels of nutrients or their metabolites in blood as one cause of metabolic stress [118-120]. Other diabetes risk factors may not directly target $\beta$-cells but have distant sites of action, such as the immune system (immune mediators), vasculature (e.g. immune mediators, adhesion molecules), fat tissue (adipokines), liver (glucose, lipids, fetuin A, immune mediators), muscle (myokines), brain (neurohormones and signals), the intestine (incretins), or microbiota (short-chain fatty acids, lipopolysaccharides). Because of the crosstalk between these organs, it is difficult to disentangle metabolic from endocrine, immunological or neuronal mechanisms of diabetes risk factors (Fig. 1). For instance, all diabetes risk factors discussed above have been reported to promote an inflammatory state and concomitant insulin resistance [121-124]. Conversely, diabetes-protective factors appear to exhibit anti-inflammatory activity [125]. Exposure to road traffic or fine dust is associated with increased serum levels of C-reactive protein or white blood cells [126, 127]. Sleep deprivation is associated with increased inflammatory reactivity, even after

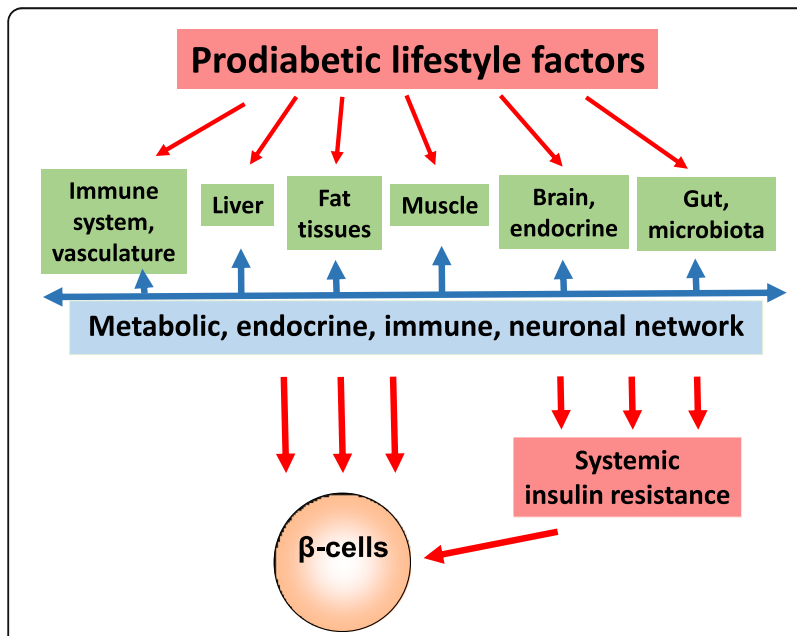

Fig. 1 Prodiabetic lifestyle factors target regulatory networks. Although the widely different lifestyle-defined diabetes risk factors are expected to interact with different parts of the body, they probably target the metabolic, endocrine, immune and neurological network(s) and synergise in promoting $\beta$-cell damage just one night of sleep loss [128, 129]. A western diet with refined sugars/starch and saturated fat is known to promote acute (lasting 1-4 hours) upregulation of proinflammatory immune mediators [130, 131], and there is sustained low-grade systemic inflammation in the context of an increase in BMI or visceral fat mass $[132,133]$. The microbiota composition may promote systemic inflammation by causing gut leakage and release of lipopolysaccharides into the circulation $[134,135]$. Persons with a sedentary lifestyle exhibit higher concentrations of circulating pro-inflammatory mediators [136-138]. Physical activity is known to attenuate low-grade inflammation [139, 140]. Fetuin released from the liver targets the same receptor as lipopolysaccharide [141]. Depression is also closely associated with elevated levels of inflammatory mediators and, conversely, subclinical inflammation may promote the occurrence of depressive symptoms [142-144].

Neuronal activity in response to environmental conditions may also affect $\beta$-cell function. The mechanisms involved include activation of the sympathetic nervous system and the secretion of catecholamines. Further, the hypothalamus-pituitary-adrenal axis may be activated, resulting in increased systemic levels of cortisol [145-147]. The development of food addiction also translates a non-healthy lifestyle into increased diabetes risk [148].

Genome-wide association and Mendelian randomisation studies of single nucleotide polymorphisms currently do not allow the definition of a causal role of metabolic versus endocrine, immunological or neuronal mediators of environmental/lifestyle effects in diabetes development. This may be due to the fact that these genetic polymorphisms explain only approximately $15 \%$ of T2D heritability $[149,150]$.

\section{Lifestyle changes for diabetes prevention}

Trials of diabetes prevention have appreciated the contribution of lifestyle to diabetes risk. A primary strategy of such trials has been the targeting of moderate weight loss via lifestyle changes, including dietary measures and increased physical activity. After 3-4 years of such a lifestyle program in persons at high risk of T2D, there was a decrease in incident diabetes by $58 \%$ when compared to the control group in both landmark trials, namely the Diabetes Prevention Program and the Diabetes Prevention Study [151, 152]. In both trials, body weight loss during the first 2 years was only approximately $5 \%$. Nevertheless, weight reduction in obese people by just $5-10 \%$ preferentially decreased the amount of visceral fat $[153,154]$, suggesting that this is a major target of the lifestyle intervention assessed. In obese people with T2D of short duration, a very low calorie diet caused normalisation of glycaemia within 1 week, with a concomitant reduction in hepatic triacylglycerol content by 
$30 \%$, whereas body weight decreased by only $3 \%$ [155]. Further, there was substantial recovery of $\beta$-cell function after 8 weeks of a low calorie diet. A protein-rich, low calorie formula diet for meal replacement was found to substantially improve metabolic control, decrease the amount of antidiabetic medication and lower body weight in persons with insulin-treated T2D [156].

Long-term data are available from the two early diabetes prevention trials. After a mean follow-up of 15 or 9 years, respectively, the incidence of diabetes was $60 \%$ in the control group versus $52 \%$ in the intervention group in the Diabetes Prevention Program, and 56\% versus $41 \%$ in the Diabetes Prevention Study [157, 158]. Thus, the lifestyle changes in the two studies halted the progression towards overt T2D in a large fraction of study participants for a few years, but was much less effective during follow-up. In both studies, there was a substantial regain of body weight over time. It is probable that long-term maintenance of body weight reduction would have prevented progression to T2D also in the long term, since this correlation is observed in people at risk of T2D after bariatric surgery [159].

\section{Conclusions}

A host of environmental or lifestyle-dependent T2D risk factors have been described in prospective epidemiological studies, ranging from energy-dense food consumption to long-term exposure to high levels of fine dust. In these studies, the amount of personal, environmental or lifestyle aspects data that can or has been documented is limited, leaving room for confounding. For instance, the number of meals prepared at home or the frequency of tooth-brushing are rarely documented although both impact diabetes risk $[160,161]$ and may therefore confound associations with other lifestyle factors. Further, which environmental or lifestyle facotrs are associated with diabetes risk but do not bear a cause-effect relationship remains unknown.

Combining epidemiological data with the experience from intervention trials may allow to tentatively define diabetes protective factors. A consistent finding from prospective studies is the association of plant food-based diets with a lower T2D risk [14-16, 18, 20]. This fits with the outcome of the PREDIMED trial of Mediterranean diet, suggesting that the diabetes-protective effect of body weight reduction can be replaced, at least in part, by an appropriate quality diet [32]. Prebiotic plant fibres promote growth of a diverse and apparently healthy microbiota with less endotoxin leakage [162-164]. This may avoid inflammatory activation of endothelial and Kupffer cells in the liver with concomitant hepatocyte dysfunction, as usually observed in response to a western-type high-fat diet or during non-alcoholic fatty liver disease [165, 166]. A fibre-rich diet gives rise to the enhanced production of short-chain fatty acids by gut bacteria [167]. There is direct binding of these products to the free fatty acid receptor 2 on $\beta$-cells and the promotion of cell growth and function [168].

A second major diabetes-protective component of plant food are phytochemicals. A property common to most phytochemicals is the activation of cell defence and antiinflammatory genes, for instance, via the Nrf2 signalling pathway [169]. These effects occur body-wide and are also demonstrable in $\beta$-cells [170].

A third major diabetes-protective factor is exercise. Interestingly, muscle work also activates cell defence and anti-inflammatory pathways via Nrf2 signalling. There is a direct beneficial effect of exercise on $\beta$-cell function [171], and also on liver function in non-alcoholic fatty liver disease, although there is no body weight loss [172].

The strongest diabetes-protective factor appears to be the avoidance or correction of a high body fat mass, notably visceral and ectopic fat. There is rapid improvement, and often normalisation, of glucose homeostasis within the first week after bariatric surgery or initiation of a very low calorie diet $[155,173]$. After Roux-en-Y gastric bypass several rapid changes have been noted aside from the lower insulin and plasma glucose levels, including lower blood levels of leptin and branched amino acids, higher concentrations of adiponectin and bile acids, and stronger post prandial increases of GLP-1 and of the satiety peptide YY [173]. However, many of these changes are not seen after gastric banding or a very low calorie diet, such as no increased production of GLP-1 [155, 174, 175], bile acids [176, 177], peptide YY [178], or no decreased levels of branched amino acids [179]. Therefore, it seems probable that the major determinant of rapid metabolic improvement seen with Roux-en-Y gastric bypass, gastric banding or a very low calorie diet is the acute negative energy balance, which is similar for the three procedures [180,181].

Obviously, the immediate response to severely restricted calorie uptake in the days after surgery or during a very low calorie diet is substantially less post-prandial insulin production, thus alleviating stress from $\beta$-cells. The lower level of protein synthesis decreases the demand of ATP from mitochondria, thereby reducing the amount of concomitantly released radical oxygen species and allowing recovery of mitochondrial proteins from oxidative damage such as nitrosylation or carbonylation [182, 183]. Indeed, within 1 week there is partial recovery of insulin production after the introduction of a very low calorie diet, with further normalisation in the following months $[155,184]$. Recovery of $\beta$-cell function to varying extents is also seen early after gastric bypass [185-187].

A second immediate response to a very low calorie intake is the adaptation of metabolic control to the low amount of digestible carbohydrate. Such adaptation is primarily important in the liver, where most of gluconeogenesis takes place, including the synthesis of glucose from glycerol of triglycerides and metabolic breakdown of 
released fatty acids to the acetate level. Excess acetyl-CoA gives rise to acetoacetyl-CoA and, subsequently, to acetone and $B$-hydroxybutyrate. The latter (reduced) ketone can be used as a substrate for oxidative energy production in place of glucose in peripheral tissues and can pass the blood-brain barrier [188].

It has been proposed that calorie restriction mimetics may elicit similar cellular responses as seen during an acute negative balance, including an improved cellular resistance to oxidative stress and an anti-inflammatory milieu [189, 190]. Many phytochemicals have been shown to exhibit activities related to calorie restriction, including the grape polyphenol resveratrol [191], anacardic acid from cashews, curcumin from the spice turmeric, garcinol from the fruit of the Kokum tree, epigallocatechin-3-gallate from green tea, and spermidine from fermented soy beans or wheat germs [192]. Therefore, it is not surprising that plant-based diets have been recognised to partly mimic the effects of calorie restriction [193, 194].

Taken together, intervention trials of diabetes prevention indicate that long-term preservation of normoglycaemia in people at high risk of T2D is achievable. Further research on the protective mechanisms associated with physical activity, healthy eating patterns and specific food components, anti-inflammatory strategies, or with weight reduction via low calorie diet or bariatric surgery seems warranted (Box 2).

\section{Box 2 Key points}

- The global type 2 diabetes (T2D) epidemic is generally believed to result from environmental and lifestyle changes

- Diabetes risk factors include energy-dense western style diets, decreased physical activity, increased sitting and monitor viewing time, exposure to noise or fine dust, short or disturbed sleep, smoking, stress, depression, and a low socioeconomic status

- It is suggested that the various diabetes risk factors probably target different organs of the body, but these are connected by endocrine, metabolic, immune and neurological networks

- Since the loss of insulin production is the ultimate cause of developing overt T2D, environmental and lifestyle factors must directly or indirectly cause $\beta$-cell damage

- Epidemiological studies indicate that major diabetes-protective factors comprise plant food-based diets and moderate to high intensity muscle work

- It may be possible to reproduce, at least in part, the benefits of body weight reduction by calorie restriction mimetics

\section{Acknowledgements}

SM has received non-restricted support for the conduct of trials of lifestyle change in persons at risk or with type 2 diabetes by Novartis Pharma GmbH, Boehringer Ingelheim Pharma GmbH \& Co. KG, Almased Wellness GmbH, Nintendo of Europe $\mathrm{GmbH}$, HMM Holding AG.

\section{Funding}

This work was supported by the Gesellschaft von Freunden und Förderern der Heinrich-Heine-Universität Düsseldorf e.V.

\section{Availability of data and materials}

Not applicable.

\section{Authors' contributions}

HK and SM conceived and wrote the manuscript. Both authors read and approved the final manuscript.

Ethics approval and consent to participate

Not applicable.

\section{Consent for publication}

Not applicable.

\section{Competing interests}

The authors declare that they have no competing interests.

\section{Publisher's Note}

Springer Nature remains neutral with regard to jurisdictional claims in published maps and institutional affiliations.

Received: 14 March 2017 Accepted: 23 June 2017

Published online: 19 July 2017

\section{References}

1. NDC Risk Factor Collaboration. Worldwide trends in diabetes since 1980: a pooled analysis of 751 population-based studies with 4.4 million participants. Lancet. 2016;387:1513-30.

2. Chatterjee S, Khunti K, Davies MJ. Type 2 diabetes. Lancet. 2017;389(10085): 2239-51. doi:10.1016/50140-6736(17)30058-2.

3. Ng M, Fleming T, Robinson M, Thomson B, Graetz N, Margono C, et al. Global, regional, and national prevalence of overweight and obesity in children and adults during 1980-2013: a systematic analysis for the Global Burden of Disease Study 2013. Lancet. 2014;384:766-81.

4. Neeland IJ, Turer AT, Ayers CR, Powell-Wiley TM, Vega GL, Farzaneh-Far R, et al. Dysfunctional adiposity and the risk of prediabetes and type 2 diabetes in obese adults. JAMA. 2012;308:1150-9.

5. Ballestri S, Zona S, Targher G, Romagnoli D, Baldelli E, Nascimbeni F, et al. Nonalcoholic fatty liver disease is associated with an almost twofold increased risk of incident type 2 diabetes and metabolic syndrome. Evidence from a systematic review and meta-analysis. J Gastroenterol Hepatol. 2016:31:936-44.

6. Valenti L, Bugianesi E, Pajvani U, Targher G. Nonalcoholic fatty liver disease: cause or consequence of type 2 diabetes? Liver Int. 2016;36:1563-79.

7. Sattar N, Gill JM. Type 2 diabetes as a disease of ectopic fat? BMC Med. 2014;12:123.

8. Phillips CM. Metabolically healthy obesity: definitions, determinants and clinical implications. Rev Endocr Metab Disord. 2013;14:219-27.

9. Roberson LL, Aneni EC, Maziak W, Agatston A, Feldman T, Rouseff M, et al. Beyond BMI: The "Metabolically healthy obese" phenotype \& its association with clinical/subclinical cardiovascular disease and all-cause mortality - a systematic review. BMC Public Health. 2014;14:14.

10. Bluher M. Are metabolically healthy obese individuals really healthy? Eur J Endocrinol. 2014:171:R209-19.

11. Ma RC, Chan JC. Type 2 diabetes in East Asians: similarities and differences with populations in Europe and the United States. Ann N Y Acad Sci. 2013; 1281:64-91.

12. Unnikrishnan R, Anjana RM, Mohan V. Diabetes in South Asians: is the phenotype different? Diabetes. 2014;63:53-5.

13. Ding C, Chan Z, Magkos F. Lean, but not healthy: the 'metabolically obese, normal-weight' phenotype. Curr Opin Clin Nutr Metab Care. 2016;19:408-17. 
14. Jannasch F, Kroger J, Schulze MB. Dietary patterns and type 2 diabetes: a systematic literature review and meta-analysis of prospective studies. J Nutr. 2017;147(6):1174-82.

15. Schwingshackl L, Hoffmann G, Lampousi AM, Knuppel S, labal K, Schwedhelm C, et al. Food groups and risk of type 2 diabetes mellitus: a systematic review and meta-analysis of prospective studies. Eur J Epidemiol. 2017. doi:10.1007/s10654-017-0246-y.

16. Fardet A, Boirie $Y$. Associations between food and beverage groups and major diet-related chronic diseases: an exhaustive review of pooled/metaanalyses and systematic reviews. Nutr Rev. 2014;72:741-62.

17. Forouhi NG, Wareham NJ. The EPIC-InterAct Study: a study of the interplay between genetic and lifestyle behavioral factors on the risk of type 2 diabetes in European populations. Curr Nutr Rep. 2014;3:355-63.

18. Maki KC, Phillips AK. Dietary substitutions for refined carbohydrate that show promise for reducing risk of type 2 diabetes in men and women. $J$ Nutr. 2015;145:159S-63S.

19. Cespedes EM, Hu FB, Tinker L, Rosner B, Redline S, Garcia L, et al. Multiple healthful dietary patterns and type 2 diabetes in the Women's Health Initiative. Am J Epidemiol. 2016;183:622-33.

20. Satija A, Bhupathiraju SN, Rimm EB, Spiegelman D, Chiuve SE, Borgi L, et al. Plant-based dietary patterns and incidence of type 2 diabetes in US men and women: results from three prospective cohort studies. PLoS Med. 2016; 13, e1002039.

21. Ma Y, He FJ, Yin Y, Hashem KM, MacGregor GA. Gradual reduction of sugar in soft drinks without substitution as a strategy to reduce overweight, obesity, and type 2 diabetes: a modelling study. Lancet Diabetes Endocrinol. 2016;4:105-14.

22. Lofvenborg JE, Andersson T, Carlsson PO, Dorkhan M, Groop L, Martinell M, et al. Sweetened beverage intake and risk of latent autoimmune diabetes in adults (LADA) and type 2 diabetes. Eur J Endocrinol. 2016;175:605-14.

23. Wang M, Yu M, Fang L, Hu RY. Association between sugar-sweetened beverages and type 2 diabetes: a meta-analysis. J Diabetes Investig. 2015;6:360-6.

24. Greenwood DC, Threapleton DE, Evans CE, Cleghorn CL, Nykjaer C, Woodhead C, Burley VJ. Association between sugar-sweetened and artificially sweetened soft drinks and type 2 diabetes: systematic review and dose-response metaanalysis of prospective studies. Br J Nutr. 2014;112:725-34.

25. Bao Y, Han J, Hu FB, Giovannucci EL, Stampfer MJ, Willett WC, Fuchs CS. Association of nut consumption with total and cause-specific mortality. N Engl J Med. 2013:369:2001-11.

26. U.S. Department of Health and Human Services. 2015-2020 Dietary Guidelines for Americans. https://health.gov/dietaryguidelines/2015/. Accessed 1 June 2017.

27. Atallah R, Filion KB, Wakil SM, Genest J, Joseph L, Poirier P, et al. Long-term effects of 4 popular diets on weight loss and cardiovascular risk factors: a systematic review of randomized controlled trials. Circ Cardiovasc Qual Outcomes. 2014;7:815-27.

28. Tay J, Luscombe-Marsh ND, Thompson CH, Noakes M, Buckley JD, Wittert GA, et al. A very low-carbohydrate, low-saturated fat diet for type 2 diabetes management: a randomized trial. Diabetes Care. 2014;37:2909-18.

29. Yancy Jr WS, Mayer SB, Coffman CJ, Smith VA, Kolotkin RL, Geiselman PJ, et al. Effect of allowing choice of diet on weight loss: a randomized trial. Ann Intern Med. 2015;162:805-14.

30. Hill AM, Harris Jackson KA, Roussell MA, West SG, Kris-Etherton PM. Type and amount of dietary protein in the treatment of metabolic syndrome: a randomized controlled trial. Am J Clin Nutr. 2015;102:757-70.

31. Tobias DK, Chen M, Manson JE, Ludwig DS, Willett W, Hu FB. Effect of lowfat diet interventions versus other diet interventions on long-term weight change in adults: a systematic review and meta-analysis. Lancet Diabetes Endocrinol. 2015;3:968-79.

32. Salas-Salvado J, Bullo M, Babio N, Martinez-Gonzalez MA, Ibarrola-Jurado N, Basora J, et al. Reduction in the incidence of type 2 diabetes with the Mediterranean diet: results of the PREDIMED-Reus nutrition intervention randomized trial. Diabetes Care. 2011:34:14-9.

33. Howells L, Musaddaq B, McKay AJ, Majeed A. Clinical impact of lifestyle interventions for the prevention of diabetes: an overview of systematic reviews. BMJ Open. 2016;6, e013806.

34. Gong QH, Kang JF, Ying YY, Li H, Zhang XH, Wu YH, Xu GZ. Lifestyle interventions for adults with impaired glucose tolerance: a systematic review and meta-analysis of the effects on glycemic control. Intern Med. 2015;54:303-10.

35. Vasto S, Buscemi S, Barera A, Di Carlo M, Accardi G, Caruso C. Mediterranean diet and healthy ageing: a Sicilian perspective. Gerontology. 2014;60:508-18.
36. Willcox DC, Scapagnini G, Willcox BJ. Healthy aging diets other than the Mediterranean: a focus on the Okinawan diet. Mech Ageing Dev. 2014;136-137:148-62.

37. Buettner D. The secrets of long life. National Geographic 2005; November. http://ngm.nationalgeographic.com/2005/11/longevity-secrets/buettner-text. Accessed 21 Mar 2017.

38. Cai D, Zhao S, Li D, Chang F, Tian X, Huang G, et al. Nutrient intake is associated with longevity characterization by metabolites and element profiles of healthy centenarians. Nutrients. 2016;8:564.

39. Shadyab AH, LaCroix AZ. Genetic factors associated with longevity: a review of recent findings. Ageing Res Rev. 2015;19:1-7.

40. Loef $\mathrm{M}$, Walach $\mathrm{H}$. The combined effects of healthy lifestyle behaviors on all cause mortality: a systematic review and meta-analysis. Prev Med. 2012:55:163-70.

41. Aune D, Norat T, Leitzmann M, Tonstad S, Vatten LJ. Physical activity and the risk of type 2 diabetes: a systematic review and dose-response metaanalysis. Eur J Epidemiol. 2015;30:529-42.

42. Smith AD, Crippa A, Woodcock J, Brage S. Physical activity and incident type 2 diabetes mellitus: a systematic review and dose-response metaanalysis of prospective cohort studies. Diabetologia. 2016:59:2527-45.

43. DiPietro L, Gribok A, Stevens MS, Hamm LF, Rumpler W. Three 15-min bouts of moderate postmeal walking significantly improves $24-\mathrm{h}$ glycemic control in older people at risk for impaired glucose tolerance. Diabetes Care. 2013; 36:3262-8.

44. Parker L, Shaw CS, Banting L, Levinger I, Hill KM, McAinch AJ, Stepto NK. Acute low-volume high-intensity interval exercise and continuous moderate-intensity exercise elicit a similar improvement in 24-h glycemic control in overweight and obese adults. Front Physiol. 2016;7:661.

45. Yates T, Henson J, Edwardson C, Dunstan D, Bodicoat DH, Khunti K, Davies MJ. Objectively measured sedentary time and associations with insulin sensitivity: Importance of reallocating sedentary time to physical activity. Prev Med. 2015;76:79-83

46. Johns DJ, Hartmann-Boyce J, Jebb SA, Aveyard P. Diet or exercise interventions vs combined behavioral weight management programs: a systematic review and meta-analysis of direct comparisons. J Acad Nutr Diet. 2014;114:1557-68.

47. Hamilton MT, Hamilton DG, Zderic TW. Sedentary behavior as a mediator of type 2 diabetes. Med Sport Sci. 2014;60:11-26.

48. de Rezende LF, Rey-Lopez JP, Matsudo VK, do Carmo LO. Sedentary behavior and health outcomes among older adults: a systematic review. BMC Public Health. 2014;14:333.

49. Rockette-Wagner B, Edelstein S, Venditti EM, Reddy D, Bray GA, CarrionPetersen $M L$, et al. The impact of lifestyle intervention on sedentary time in individuals at high risk of diabetes. Diabetologia. 2015;58:1198-202.

50. Biswas A, Oh PI, Faulkner GE, Bajaj RR, Silver MA, Mitchell MS, Alter DA. Sedentary time and its association with risk for disease incidence, mortality, and hospitalization in adults: a systematic review and meta-analysis. Ann Intern Med. 2015;162:123-32.

51. Dempsey PC, Owen N, Yates TE, Kingwell BA, Dunstan DW. Sitting less and moving more: improved glycaemic control for type 2 diabetes prevention and management. Curr Diab Rep. 2016;16:114

52. Golubic R, Wijndaele K, Sharp SJ, Simmons RK, Griffin SJ, Wareham NJ, et al. Physical activity, sedentary time and gain in overall and central body fat: 7-year follow-up of the ProActive trial cohort. Int J Obes (Lond). 2015:39:142-8.

53. Levine JA. Sick of sitting. Diabetologia. 2015;58:1751-8.

54. Levine JA, Schleusner SJ, Jensen MD. Energy expenditure of nonexercise activity. Am J Clin Nutr. 2000;72:1451-4

55. Sorensen M, Andersen ZJ, Nordsborg RB, Becker T, Tjonneland A, Overvad K, Raaschou-Nielsen O. Long-term exposure to road traffic noise and incident diabetes: a cohort study. Environ Health Perspect. 2013;121:217-22.

56. Heidemann C, Niemann H, Paprott R, Du Y, Rathmann W, Scheidt-Nave C. Residential traffic and incidence of type 2 diabetes: the German Health Interview and Examination Surveys. Diabet Med. 2014:31:1269-76.

57. Eze IC, Schaffner E, Foraster M, Imboden M, von Eckardstein A, Gerbase MW et al. Long-term exposure to ambient air pollution and metabolic syndrome in adults. PLoS One. 2015;10, e0130337.

58. Weinmayr G, Hennig F, Fuks K, Nonnemacher M, Jakobs H, Mohlenkamp S, et al. Long-term exposure to fine particulate matter and incidence of type 2 diabetes mellitus in a cohort study: effects of total and traffic-specific air pollution. Environ Health. 2015;14:53.

59. Dzhambov AM. Long-term noise exposure and the risk for type 2 diabetes: a meta-analysis. Noise Health. 2015;17:23-33. 
60. Li Y, Gao X, Winkelman JW, Cespedes EM, Jackson CL, Walters AS, et al. Association between sleeping difficulty and type 2 diabetes in women. Diabetologia. 2016;59:719-27.

61. Miedema HM, Vos H. Associations between self-reported sleep disturbance and environmental noise based on reanalyses of pooled data from 24 studies. Behav Sleep Med. 2007;5:1-20.

62. Reynolds AC, Banks S. Total sleep deprivation, chronic sleep restriction and sleep disruption. Prog Brain Res. 2010;185:91-103.

63. Shan Z, Ma H, Xie M, Yan P, Guo Y, Bao W, et al. Sleep duration and risk of type 2 diabetes: a meta-analysis of prospective studies. Diabetes Care. 2015; 38:529-37.

64. Xi B, He D, Zhang M, Xue J, Zhou D. Short sleep duration predicts risk of metabolic syndrome: a systematic review and meta-analysis. Sleep Med Rev. 2014;18:293-7.

65. Kowall B, Lehnich AT, Strucksberg KH, Fuhrer D, Erbel R, Jankovic N, et al. Associations among sleep disturbances, nocturnal sleep duration, daytime napping, and incident prediabetes and type 2 diabetes: the Heinz Nixdorf Recall Study. Sleep Med. 2016;21:35-41.

66. Leng Y, Cappuccio FP, Surtees PG, Luben R, Brayne C, Khaw KT. Daytime napping, sleep duration and increased 8-year risk of type 2 diabetes in a British population. Nutr Metab Cardiovasc Dis. 2016;26:996-1003.

67. Rao MN, Neylan TC, Grunfeld C, Mulligan K, Schambelan M, Schwarz JM. Subchronic sleep restriction causes tissue-specific insulin resistance. J Clin Endocrinol Metab. 2015;100:1664-71.

68. Donga E, van Dijk M, van Dijk JG, Biermasz NR, Lammers GJ, van Kralingen $\mathrm{KW}$, et al. A single night of partial sleep deprivation induces insulin resistance in multiple metabolic pathways in healthy subjects. J Clin Endocrinol Metab. 2010;95:2963-8.

69. Ding M, Bhupathiraju SN, Chen M, van Dam RM, Hu FB. Caffeinated and decaffeinated coffee consumption and risk of type 2 diabetes: a systematic review and a dose-response meta-analysis. Diabetes Care. 2014;37:569-86.

70. Moisey LL, Kacker S, Bickerton AC, Robinson LE, Graham TE. Caffeinated coffee consumption impairs blood glucose homeostasis in response to high and low glycemic index meals in healthy men. Am J Clin Nutr. 2008;87:1254-61.

71. Ohnaka K, Ikeda M, Maki T, Okada T, Shimazoe T, Adachi M, et al. Effects of 16-week consumption of caffeinated and decaffeinated instant coffee on glucose metabolism in a randomized controlled trial. J Nutr Metab. 2012; 2012:207426.

72. Robertson TM, Clifford MN, Penson S, Chope G, Robertson MD. A single serving of caffeinated coffee impairs postprandial glucose metabolism in overweight men. Br J Nutr. 2015;114:1218-25.

73. Rakvaag E, Dragsted LO. Acute effects of light and dark roasted coffee on glucose tolerance: a randomized, controlled crossover trial in healthy volunteers. Eur J Nutr. 2016:55:2221-30.

74. Kempf K, Kolb H, Gartner B, Bytof G, Stiebitz H, Lantz I, et al. Cardiometabolic effects of two coffee blends differing in content for major constituents in overweight adults: a randomized controlled trial. Eur J Nutr. 2015;54:845-54

75. Wedick NM, Brennan AM, Sun Q, Hu FB, Mantzoros CS, van Dam RM. Effects of caffeinated and decaffeinated coffee on biological risk factors for type 2 diabetes: a randomized controlled trial. Nutr J. 2011;10:93.

76. Zheng XX, Xu YL, Li SH, Hui R, Wu YJ, Huang XH. Effects of green tea catechins with or without caffeine on glycemic control in adults: a metaanalysis of randomized controlled trials. Am J Clin Nutr. 2013;97:750-62.

77. Yang WS, Wang WY, Fan WY, Deng Q, Wang X. Tea consumption and risk of type 2 diabetes: a dose-response meta-analysis of cohort studies. $\mathrm{Br} J$ Nutr. 2014;111:1329-39.

78. Yang J, Mao QX, Xu HX, Ma X, Zeng CY. Tea consumption and risk of type 2 diabetes mellitus: a systematic review and meta-analysis update. BMJ Open. 2014;4, e005632

79. Knott C, Bell S, Britton A. Alcohol consumption and the risk of type 2 diabetes: a systematic review and dose-response meta-analysis of more than 1.9 million individuals from 38 observational studies. Diabetes Care. 2015;38:1804-12.

80. Li XH, Yu FF, Zhou YH, He J. Association between alcohol consumption and the risk of incident type 2 diabetes: a systematic review and dose-response meta-analysis. Am J Clin Nutr. 2016;103:818-29.

81. Gepner Y, Golan R, Harman-Boehm I, Henkin Y, Schwarzfuchs D, Shelef I, et al. Effects of initiating moderate alcohol intake on cardiometabolic risk in adults with type 2 diabetes: a 2-year randomized, controlled trial. Ann Intern Med. 2015;163:569-79.
82. Zhang L, Curhan GC, Hu FB, Rimm EB, Forman JP. Association between passive and active smoking and incident type 2 diabetes in women. Diabetes Care. 2011;34:892-7.

83. Willi $C$, Bodenmann P, Ghali WA, Faris PD, Cornuz J. Active smoking and the risk of type 2 diabetes: a systematic review and meta-analysis. JAMA. 2007; 298:2654-64.

84. Pan A, Wang Y, Talaei M, Hu FB, Wu T. Relation of active, passive, and quitting smoking with incident type 2 diabetes: a systematic review and meta-analysis. Lancet Diabetes Endocrinol. 2015;3:958-67.

85. Keith RJ, Al Rifai M, Carruba C, De Jarnett N, McEvoy JW, Bhatnagar A, et al. Tobacco use, insulin resistance, and risk of type 2 diabetes: results from the multi-ethnic study of atherosclerosis. PLoS One. 2016;11, e0157592.

86. Virtanen M, Ferrie JE, Tabak AG, Akbaraly TN, Vahtera J, Singh-Manoux A, Kivimaki M. Psychological distress and incidence of type 2 diabetes in highrisk and low-risk populations: the Whitehall II Cohort Study. Diabetes Care. 2014;37:2091-7.

87. Bergmann N, Gyntelberg F, Faber J. The appraisal of chronic stress and the development of the metabolic syndrome: a systematic review of prospective cohort studies. Endocr Connect. 2014;3:R55-80.

88. Cosgrove MP, Sargeant LA, Caleyachetty R, Griffin SJ. Work-related stress and type 2 diabetes: systematic review and meta-analysis. Occup Med (Lond). 2012;62:167-73.

89. Pouwer F, Kupper N, Adriaanse MC. Does emotional stress cause type 2 diabetes mellitus? A review from the European Depression in Diabetes (EDID) Research Consortium. Discov Med. 2010;9:112-18.

90. Rutters F, Pilz S, Koopman AD, Rauh SP, Pouwer F, Stehouwer CD, et al. Stressful life events and incident metabolic syndrome: the Hoorn study. Stress. 2015;18:507-13.

91. Novak M, Bjorck L, Giang KW, Heden-Stahl C, Wilhelmsen L, Rosengren A. Perceived stress and incidence of type 2 diabetes: a 35-year follow-up study of middle-aged Swedish men. Diabet Med. 2013;30:e8-16.

92. Melamed S, Shirom A, Toker S, Shapira I. Burnout and risk of type 2 diabetes: a prospective study of apparently healthy employed persons. Psychosom Med. 2006:68:863-9.

93. Ford AH, Flicker L, Hankey GJ, Yeap BB, Chubb SA, Golledge J, Almeida OP. Insulin resistance and depressive symptoms in older men: the health in men study. Am J Geriatr Psychiatry. 2015;23:872-80.

94. Au B, Smith KJ, Gariepy G, Schmitz N. C-reactive protein, depressive symptoms, and risk of diabetes: results from the English Longitudinal Study of Ageing (ELSA). J Psychosom Res. 2014;77:180-6.

95. Hasan SS, Clavarino AM, Mamun AA, Kairuz T. Incidence and risk of diabetes mellitus associated with depressive symptoms in adults: evidence from longitudinal studies. Diabetes Metab Syndr. 2014;8:82-7.

96. Demakakos P, Zaninotto P, Nouwen A. Is the association between depressive symptoms and glucose metabolism bidirectional? Evidence from the English Longitudinal Study of Ageing. Psychosom Med. 2014;76:555-61.

97. Khambaty T, Callahan CM, Perkins AJ, Stewart JC. Depression and anxiety screens as simultaneous predictors of 10-year incidence of diabetes mellitus in older adults in primary care. J Am Geriatr Soc. 2016;65:294-300.

98. Meisinger C, Kandler U, Ladwig KH. Living alone is associated with an increased risk of type 2 diabetes mellitus in men but not women from the general population: the MONICA/KORA Augsburg Cohort Study. Psychosom Med. 2009;71:784-8.

99. Agardh E, Allebeck P, Hallqvist J, Moradi T, Sidorchuk A. Type 2 diabetes incidence and socio-economic position: a systematic review and metaanalysis. Int J Epidemiol. 2011;40:804-18.

100. Sommer I, Griebler U, Mahlknecht P, Thaler K, Bouskill K, Gartlehner G, Mendis S. Socioeconomic inequalities in non-communicable diseases and their risk factors: an overview of systematic reviews. BMC Public Health. 2015;15:914

101. Stringhini S, Zaninotto P, Kumari M, Kivimaki M, Batty GD. Lifecourse socioeconomic status and type 2 diabetes: the role of chronic inflammation in the English Longitudinal Study of Ageing. Sci Rep. 2016;6:24780.

102. Sacerdote C, Ricceri F, Rolandsson O, Baldi I, Chirlaque MD, Feskens E, et al. Lower educational level is a predictor of incident type 2 diabetes in European countries: the EPIC-InterAct study. Int J Epidemiol. 2012;41:1162-73.

103. Williams ED, Tapp RJ, Magliano DJ, Shaw JE, Zimmet PZ, Oldenburg BF. Health behaviours, socioeconomic status and diabetes incidence: the Australian Diabetes Obesity and Lifestyle Study (AusDiab). Diabetologia. 2010;53:2538-45.

104. Leong A, Rahme E, Dasgupta K. Spousal diabetes as a diabetes risk factor: a systematic review and meta-analysis. BMC Med. 2014;12:12. 
105. Almgren M, Atkinson R, He J, Hilding A, Hagman E, Wolk A, et al. Adenovirus-36 is associated with obesity in children and adults in Sweden as determined by rapid ELISA. PLoS One. 2012;7, e41652.

106. Pasarica M, Shin AC, Yu M, Ou Yang HM, Rathod M, et al. Human adenovirus 36 induces adiposity, increases insulin sensitivity, and alters hypothalamic monoamines in rats. Obesity (Silver Spring). 2006;14:1905-13.

107. Almgren $M$, Atkinson RL, Hilding A, He J, Brismar $K$, Schalling $M$, et al. Human adenovirus-36 is uncommon in type 2 diabetes and is associated with increased insulin sensitivity in adults in Sweden. Ann Med. 2014;46:539-46.

108. Negro F. Facts and fictions of HCV and comorbidities: steatosis, diabetes mellitus, and cardiovascular diseases. J Hepatol. 2014;61:S69-78.

109. Lin YJ, Shaw TG, Yang HI, Lu SN, Jen CL, Wang LY, et al. Chronic hepatitis C virus infection and the risk for diabetes: a community-based prospective study. Liver Int. 2016;92:279-82.

110. Rodriguez AR, Plascencia-Villa G, Witt CM, Yu JJ, Jose-Yacaman M, Chambers $J$, et al. Chlamydia pneumoniae promotes dysfunction of pancreatic beta cells. Cell Immunol. 2015;295:83-91.

111. Betene AD, De Wit S, Neuhaus J, Palfreeman A, Pepe R, Pankow JS, Neaton JD. Interleukin-6, high sensitivity C-reactive protein, and the development of type 2 diabetes among HIV-positive patients taking antiretroviral therapy. J Acquir Immune Defic Syndr. 2014;67:538-46.

112. Bonnefond A, Froguel P. Rare and common genetic events in type 2 diabetes: what should biologists know? Cell Metab. 2015;21:357-68.

113. Esparza-Romero J, Valencia ME, Urquidez-Romero R, Chaudhari LS, Hanson RL, Knowler WC, et al. Environmentally driven increases in type 2 diabetes and obesity in Pima Indians and non-Pimas in Mexico over a 15-year period: the Maycoba Project. Diabetes Care. 2015;38:2075-82.

114. Lao XQ, Ma WJ, Sobko T, Zhang YH, Xu YJ, Xu XJ, et al. Overall obesity is leveling-off while abdominal obesity continues to rise in a Chinese population experiencing rapid economic development: analysis of serial cross-sectional health survey data 2002-2010. Int J Obes (Lond). 2015;39:288-94.

115. Wang Y, Rimm EB, Stampfer MJ, Willett WC, Hu FB. Comparison of abdominal adiposity and overall obesity in predicting risk of type 2 diabetes among men. Am J Clin Nutr. 2005;81:555-63.

116. Hardoon SL, Morris RW, Thomas MC, Wannamethee SG, Lennon LT, Whincup PH. Is the recent rise in type 2 diabetes incidence from 1984 to 2007 explained by the trend in increasing BMI?: evidence from a prospective study of British men. Diabetes Care. 2010;33:1494-6.

117. Butler AE, Dhawan S, Hoang J, Cory M, Zeng K, Fritsch H, et al. $\beta$-cell deficit in obese type 2 diabetes, a minor role of $\beta$-cell dedifferentiation and degranulation. J Clin Endocrinol Metab. 2016;101:523-32.

118. Kaneto H. Pancreatic beta-cell glucose toxicity in type 2 diabetes mellitus. Curr Diabetes Rev. 2015;11:2-6.

119. Brun T, Maechler P. Beta-cell mitochondrial carriers and the diabetogenic stress response. Biochim Biophys Acta. 1863;2016:2540-9.

120. Ertunc ME, Hotamisligil GS. Lipid signaling and lipotoxicity in metaflammation: indications for metabolic disease pathogenesis and treatment. J Lipid Res. 2016;57:2099-114.

121. Kolb H, Mandrup-Poulsen T. The global diabetes epidemic as a consequence of lifestyle-induced low-grade inflammation. Diabetologia. 2010;53:10-20.

122. McNelis JC, Olefsky JM. Macrophages, immunity, and metabolic disease. Immunity. 2014:41:36-48.

123. Herder C, Dalmas E, Boni-Schnetzler M, Donath MY. The IL-1 Pathway in type 2 diabetes and cardiovascular complications. Trends Endocrinol Metab. 2015;26:551-63.

124. Berchtold LA, Prause M, Storling J, Mandrup-Poulsen T. Cytokines and pancreatic beta-cell apoptosis. Adv Clin Chem. 2016;75:99-158.

125. Kolb H, Eizirik DL. Resistance to type 2 diabetes mellitus: a matter of hormesis? Nat Rev Endocrinol. 2012;8:183-92.

126. Lanki T, Hampel R, Tiittanen P, Andrich S, Beelen R, Brunekreef B, et al. Air pollution from road traffic and systemic inflammation in adults: a crosssectional analysis in the European ESCAPE Project. Environ Health Perspect. 2015:123:785-91.

127. Chen JC, Schwartz J. Metabolic syndrome and inflammatory responses to long-term particulate air pollutants. Environ Health Perspect. 2008;116:612-7.

128. da Costa SA, Ribeiro S. Sleep deprivation and gene expression. Curr Top Behav Neurosci. 2015;25:65-90.

129. Chennaoui M, Sauvet F, Drogou C, Van Beers P, Langrume C, Guillard M, et al. Effect of one night of sleep loss on changes in tumor necrosis factor alpha (TNF-alpha) levels in healthy men. Cytokine. 2011;56:318-24.
130. de Vries MA, Klop B, Janssen HW, Njo TL, Westerman EM, Castro CM. Postprandial inflammation: targeting glucose and lipids. Adv Exp Med Biol. 2014;824:161-70.

131. Herieka M, Erridge C. High-fat meal induced postprandial inflammation. Mol Nutr Food Res. 2014;58:136-46.

132. Thorand B, Baumert J, Doring A, Herder C, Kolb H, Rathmann W, et al. Sex differences in the relation of body composition to markers of inflammation. Atherosclerosis. 2006;184:216-24.

133. Choi J, Joseph L, Pilote L. Obesity and C-reactive protein in various populations: a systematic review and meta-analysis. Obes Rev. 2013;14:232-44.

134. Gnauck A, Lentle RG, Kruger MC. The characteristics and function of bacterial lipopolysaccharides and their endotoxic potential in humans. Int Rev Immunol. 2016;35:189-218.

135. Amyot J, Semache M, Ferdaoussi M, Fontes G, Poitout V. Lipopolysaccharides impair insulin gene expression in isolated islets of Langerhans via Toll-like receptor-4 and NF-kappaB signalling. PLoS One. 2012;7, e36200

136. Martinez-Gomez D, Eisenmann JC, Healy GN, Gomez-Martinez S, Diaz LE, Dunstan DW, et al. Sedentary behaviors and emerging cardiometabolic biomarkers in adolescents. J Pediatr. 2012;160:104-10.

137. Henson J, Yates T, Edwardson CL, Khunti K, Talbot D, Gray L, et al. Sedentary time and markers of chronic low-grade inflammation in a high risk population. PLoS One. 2013;8, e78350.

138. Gabel L, Ridgers ND, Della Gatta PA, Arundell L, Cerin E, Robinson S, et al. Associations of sedentary time patterns and TV viewing time with inflammatory and endothelial function biomarkers in children. Pediatr Obes. 2015;11:194-201.

139. You T, Arsenis NC, Disanzo BL, Lamonte MJ. Effects of exercise training on chronic inflammation in obesity : current evidence and potential mechanisms. Sports Med. 2013:43:243-56.

140. Gjevestad GO, Holven KB, Ulven SM. Effects of exercise on gene expression of inflammatory markers in human peripheral blood cells: a systematic review. Curr Cardiovasc Risk Rep. 2015;9:34.

141. Shen X, Yang L, Yan S, Zheng H, Liang L, Cai X, Liao M. Fetuin A promotes lipotoxicity in beta cells through the TLR4 signaling pathway and the role of pioglitazone in anti-lipotoxicity. Mol Cell Endocrinol. 2015:412:1-11.

142. Howren MB, Lamkin DM, Suls J. Associations of depression with C-reactive protein, IL-1, and IL-6: a meta-analysis. Psychosom Med. 2009;71:171-86.

143. Berk M, Williams L, Jacka FN, O'Neil A, Pasco JA, Moylan S, et al. So depression is an inflammatory disease, but where does the inflammation come from? BMC Med. 2013;11:200

144. Kiecolt-Glaser JK, Derry HM, Fagundes CP. Inflammation: depression fans the flames and feasts on the heat. Am J Psychiatry. 2015;172:1075-91.

145. Kruyt ND, van Westerloo DJ, DeVries JH. Stress-induced hyperglycemia in healthy bungee jumpers without diabetes due to decreased pancreatic beta-cell function and increased insulin resistance. Diabetes Technol Ther. 2012:14:311-4.

146. Maffei A, Segal AM, Alvarez-Perez JC, Garcia-Ocana A, Harris PE. Anti-incretin anti-proliferative action of dopamine on beta-cells. Mol Endocrinol. 2015;29: 542-57.

147. Kodavanti UP. Stretching the stress boundary: linking air pollution health effects to a neurohormonal stress response. Biochim Biophys Acta. 1860; 2016:2880-90.

148. Carter A, Hendrikse J, Lee N, Yucel M, Verdejo-Garcia A, Andrews Z, Hall W. The neurobiology of "food addiction" and its implications for obesity treatment and policy. Annu Rev Nutr. 2016;36:105-28.

149. Fuchsberger C, Flannick J, Teslovich TM, Mahajan A, Agarwala V, Gaulton KJ, et al. The genetic architecture of type 2 diabetes. Nature. 2016;536:41-7.

150. Swerdlow DI. Mendelian randomization and type 2 diabetes. Cardiovasc Drugs Ther. 2016;30:51-7.

151. Delahanty LM, Pan Q, Jablonski KA, Aroda VR, Watson KE, Bray GA, et al. Effects of weight loss, weight cycling, and weight loss maintenance on diabetes incidence and change in cardiometabolic traits in the Diabetes Prevention Program. Diabetes Care. 2014;37:2738-45.

152. Tuomilehto J, Lindstrom J, Eriksson JG, Valle TT, Hamalainen H, llanneParikka $\mathrm{P}$, et al. Prevention of type 2 diabetes mellitus by changes in lifestyle among subjects with impaired glucose tolerance. N Engl J Med. 2001;344: $1343-50$.

153. Chaston TB, Dixon JB. Factors associated with percent change in visceral versus subcutaneous abdominal fat during weight loss: findings from a systematic review. Int J Obes (Lond). 2008;32:619-28. 
154. Gallagher D, Heshka S, Kelley DE, Thornton J, Boxt L, Pi-Sunyer FX, et al. Changes in adipose tissue depots and metabolic markers following a 1-year diet and exercise intervention in overweight and obese patients with type 2 diabetes. Diabetes Care. 2014:37:3325-32.

155. Lim EL, Hollingsworth KG, Aribisala BS, Chen MJ, Mathers JC, Taylor R. Reversal of type 2 diabetes: normalisation of beta cell function in association with decreased pancreas and liver triacylglycerol. Diabetologia. 2011:54:2506-14

156. Kempf K, Schloot NC, Gartner B, Keil R, Schadewaldt P, Martin S. Meal replacement reduces insulin requirement, $\mathrm{HbA1}$ and weight long-term in type 2 diabetes patients with $>100 \mathrm{U}$ insulin per day. J Hum Nutr Diet. 2014;27 Suppl 2:21-7.

157. Diabetes Prevention Program Research Group. Long-term effects of lifestyle intervention or metformin on diabetes development and microvascular complications over 15-year follow-up: the Diabetes Prevention Program Outcomes Study. Lancet Diabetes Endocrinol. 2015;3:866-75.

158. Lindstrom J, Peltonen M, Eriksson JG, llanne-Parikka P, Aunola S, KeinanenKiukaanniemi S, et al. Improved lifestyle and decreased diabetes risk over 13 years: long-term follow-up of the randomised Finnish Diabetes Prevention Study (DPS). Diabetologia. 2013;56:284-93.

159. Sjoholm K, Sjostrom E, Carlsson LM, Peltonen M. Weight change-adjusted effects of gastric bypass surgery on glucose metabolism: 2- and 10-year results from the Swedish Obese Subjects (SOS) study. Diabetes Care. 2016:39:625-31.

160. Zong G, Eisenberg DM, Hu FB, Sun Q. Consumption of meals prepared at home and risk of type 2 diabetes: an analysis of two prospective cohort studies. PLoS Med. 2016;13, e1002052

161. Kuwabara M, Motoki Y, Sato H, Fujii M, Ichiura K, Kuwabara K, Nakamura Y. Low frequency of toothbrushing practices is an independent risk factor for diabetes mellitus in male and dyslipidemia in female: A large-scale, 5-year cohort study in Japan. J Cardiol. 2016. doi:10.1016/j.jjcc.2016.10.008.

162. Brandsma E, Houben T, Fu J, Shiri-Sverdlov R, Hofker MH. The immunitydiet-microbiota axis in the development of metabolic syndrome. Curr Opin Lipidol. 2015;26:73-81.

163. Delzenne NM, Cani PD, Everard A, Neyrinck AM, Bindels LB. Gut microorganisms as promising targets for the management of type 2 diabetes. Diabetologia. 2015;58:2206-17.

164. Xiao S, Fei N, Pang X, Shen J, Wang L, Zhang B, et al. A gut microbiotatargeted dietary intervention for amelioration of chronic inflammation underlying metabolic syndrome. FEMS Microbiol Ecol. 2014;87:357-67.

165. Miele L, Valenza V, La Torre G, Montalto M, Cammarota G, Ricci R, et al. Increased intestinal permeability and tight junction alterations in nonalcoholic fatty liver disease. Hepatology. 2009;49:1877-87.

166. Festi D, Schiumerini R, Eusebi LH, Marasco G, Taddia M, Colecchia A. Gut microbiota and metabolic syndrome. World J Gastroenterol. 2014;20:16079-94.

167. Boets E, Gomand SV, Deroover L, Preston T, Vermeulen K, De Preter V, et al. Systemic availability and metabolism of colonic-derived short-chain fatty acids in healthy subjects: a stable isotope study. J Physiol. 2017:595:541-55.

168. Priyadarshini M, Wicksteed B, Schiltz GE, Gilchrist A, Layden BT. SCFA receptors in pancreatic beta cells: novel diabetes targets? Trends Endocrinol Metab. 2016;27:653-64

169. Stefanson AL, Bakovic M. Dietary regulation of Keap1/Nrf2/ARE pathway: focus on plant-derived compounds and trace minerals. Nutrients. 2014;6: 3777-801.

170. Qin S, Hou DX. Multiple regulations of Keap1/Nrf2 system by dietary phytochemicals. Mol Nutr Food Res. 2016;60:1731-55.

171. Li T, He S, Liu S, Kong Z, Wang J, Zhang Y. Effects of different exercise durations on Keap1-Nrf2-ARE pathway activation in mouse skeletal muscle. Free Radic Res. 2015;49:1269-74.

172. Keating SE, Hackett DA, George J, Johnson NA. Exercise and non-alcoholic fatty liver disease: a systematic review and meta-analysis. J Hepatol. 2012;57:157-66.

173. Nguyen KT, Korner J. The sum of many parts: potential mechanisms for improvement in glucose homeostasis after bariatric surgery. Curr Diab Rep. 2014;14:481.

174. Korner J, Bessler M, Inabnet W, Taveras C, Holst JJ. Exaggerated glucagonlike peptide-1 and blunted glucose-dependent insulinotropic peptide secretion are associated with Roux-en-Y gastric bypass but not adjustable gastric banding. Surg Obes Relat Dis. 2007;3:597-601.

175. Svendsen PF, Jensen FK, Holst JJ, Haugaard SB, Nilas L, Madsbad S. The effect of a very low calorie diet on insulin sensitivity, beta cell function, insulin clearance, incretin hormone secretion, androgen levels and body composition in obese young women. Scand J Clin Lab Invest. 2012;72:410-9.
176. Lips MA, de Groot GH, Berends FJ, Wiezer R, Van Wagensveld BA, Swank DJ, et al. Calorie restriction and Roux-en-Y gastric bypass have opposing effects on circulating FGF21 in morbidly obese subjects. Clin Endocrinol (Oxf). 2014 81:862-70.

177. Jorgensen NB, Dirksen C, Bojsen-Moller KN, Kristiansen VB, Wulff BS, Rainteau D, Clausen TR, et al. Improvements in glucose metabolism early after gastric bypass surgery are not explained by increases in total bile acids and fibroblast growth factor 19 concentrations. J Clin Endocrinol Metab. 2015;100:E396-406.

178. Rodieux F, Giusti V, D'Alessio DA, Suter M, Tappy L. Effects of gastric bypass and gastric banding on glucose kinetics and gut hormone release. Obesity (Silver Spring). 2008;16:298-305

179. Lips MA, Van Klinken JB, van Harmelen V, Dharuri HK, 't Hoen PA, Laros JF, van Ommen GJ, et al. Roux-en-Y gastric bypass surgery, but not calorie restriction, reduces plasma branched-chain amino acids in obese women independent of weight loss or the presence of type 2 diabetes. Diabetes Care. 2014;37:3150-6.

180. Isbell JM, Tamboli RA, Hansen EN, Saliba J, Dunn JP, Phillips SE, et al. The importance of caloric restriction in the early improvements in insulin sensitivity after Roux-en-Y gastric bypass surgery. Diabetes Care. 2010;33: $1438-42$.

181. Lips MA, de Groot GH, Van Klinken JB, Aarts E, Berends FJ, Janssen IM, et al. Calorie restriction is a major determinant of the short-term metabolic effects of gastric bypass surgery in obese type 2 diabetic patients. Clin Endocrinol (Oxf). 2014;80:834-42.

182. Supale S, Li N, Brun T, Maechler P. Mitochondrial dysfunction in pancreatic beta cells. Trends Endocrinol Metab. 2012;23:477-87.

183. Peinado JR, Diaz-Ruiz A, Fruhbeck G, Malagon MM. Mitochondria in metabolic disease: getting clues from proteomic studies. Proteomics. 2014; 14:452-66.

184. Malandrucco I, Pasqualetti P, Giordani I, Manfellotto D, De Marco F, Alegiani F, et al. Very-low-calorie diet: a quick therapeutic tool to improve beta cell function in morbidly obese patients with type 2 diabetes. Am J Clin Nutr. 2012;95:609-13

185. Polyzogopoulou EV, Kalfarentzos F, Vagenakis AG, Alexandrides TK. Restoration of euglycemia and normal acute insulin response to glucose in obese subjects with type 2 diabetes following bariatric surgery. Diabetes. 2003;52:1098-103

186. Martinussen C, Bojsen-Moller KN, Dirksen C, Jacobsen SH, Jorgensen NB, Kristiansen VB, et al. Immediate enhancement of first-phase insulin secretion and unchanged glucose effectiveness in patients with type 2 diabetes after Roux-en-Y gastric bypass. Am J Physiol Endocrinol Metab. 2015;308:E535-44.

187. Nannipieri M, Mari A, Anselmino M, Baldi S, Barsotti E, Guarino D, et al. The role of beta-cell function and insulin sensitivity in the remission of type 2 diabetes after gastric bypass surgery. J Clin Endocrinol Metab. 2011;96: E1372-9.

188. Longo VD, Mattson MP. Fasting: molecular mechanisms and clinical applications. Cell Metab. 2014;19:181-92.

189. Brewer RA, Gibbs VK, Smith Jr DL. Targeting glucose metabolism for healthy aging. Nutr Healthy Aging. 2016:4:31-46.

190. Lopez-Lluch G, Navas P. Calorie restriction as an intervention in ageing. J Physiol. 2016;594:2043-60.

191. Cao Y, Jiang X, Ma H, Wang Y, Xue P, Liu Y. SIRT1 and insulin resistance. J Diabetes Complications. 2016;30:178-83.

192. Marino G, Pietrocola F, Madeo F, Kroemer G. Caloric restriction mimetics: natural/physiological pharmacological autophagy inducers. Autophagy. 2014:10:1879-82.

193. Pall ML, Levine S. Nrf2, a master regulator of detoxification and also antioxidant, anti-inflammatory and other cytoprotective mechanisms, is raised by health promoting factors. Sheng Li Xue Bao. 2015;67:1-18.

194. Rodriguez-Ramiro I, Vauzour D, Minihane AM. Polyphenols and non-alcoholic fatty liver disease: impact and mechanisms. Proc Nutr Soc. 2016;75:47-60. 